Розділ І. Ціннісні орієнтири духовно-інтелектуального виховання, розвиток духовно-інтелектуальних якостей особистості в умовах співпраці й інклюзії

\title{
ЗАСОБИ РОЗВИТКУ ВИРАЗНОСТІ РУХІВ У ЮНИХ СПОРТСМЕНІВ, ЩО ЗАЙМАЮТЬСЯ СКЛАДНОКООРДИНАЦЙННИМИ ВИДАМИ СПОРТУ
}

\author{
Кравчук Т. М. \\ кандидат педагогічних наук, доцент, заступник декана з навчальної роботи, \\ факультет фізичного виховання і спорту, Харківський національний \\ педагогічний університет імені Г. С. Сковороди, м. Харків, Україна

\section{Зеленська С. I.} \\ здобувач другого (магістерського) рівня вищої освіти, \\ Харківський національний педагогічний університет \\ імені Г. С. Сковороди, м. Харків, Україна
}

У статті подано засоби розвитку виразності рухів у юних спортсменів, щуо займаються складнокоординаційними видами спорту. Показано, щуо корисними у вихованні виразного руху можуть бути вправи партерної хореографії сюжетної забарвленості, вправи ритмічної гімнастики, танцюювальні вправи та музичні і сюжетно-рольові ігри.

Ключові слова: засоби, виразність, підготовка, розвиток, юні спортсмени.

The study selected the means of developing expressive movements in young athletes engaged in sports with complex coordination. It is shown that exercises of parterre choreography of plot coloring, exercises of rhythmic gymnastics, dance exercises and musical and plot-role-playing games can be useful in the education of expressive movement.

Keywords: means, expressiveness, preparation, development, young athletes

Сьогодні в Україні все більшу популярність здобувають види спорту пов'язані з мистецтвом рухів. Серед них художня й аеробічна гімнастика, парно-групова акробатика, акробатичний рок-н-рол, тощо. Головним завданням спортсменів, що займаються цими складнокоординаційними видами спорту, є представлення змагальної композиції, яка має складатися з базових рухів, елементів різних груп складності, акробатичних і танцювальних вправ. Все це різноманіття складних за технікою рухів має бути поєднане у композицію що несе художню цінність. Створити за допомогою рухів тіла художній образ, що донесе до глядачів і суддів певний емоційний заряд, спортсмени 
можуть завдяки виразності рухів, яку слід розвивати починаючи 3 раннього віку.

Окремі питання рухової та пластичної виразності в складнокоординаційних видах спорту досліджували Ж Горбачева (2000), Л. Гончаренко (1987) О. Горшкова (2003), А. Кабаєва, М. Плеханова (2009), Н. Каравацька (2002), Л. Карпенко, О. Румба (2001), О. Омельянчик (2001), В. Тодорова (2018) та інші. Автори визначили основні компоненти виконавської майстерності, до яких увійшли: пластика, виразність, акторська майстерність, експресія рухів тощо. 3 метою вдосконалення виконавської майстерності дослідники рекомендують головну увагу приділяти технічній та хореографічній підготовці гімнасток, а також особливостям складання змагальних композицій та добору музичного супроводу до них.

У попередніх роботах Т. Кравчук (2010) та Т. Кравчук, Н. Санжарової, А. Удовика (2018) розглядалися окремі питання формування рухово-пластичної виразності на етапі спеціалізованої базової підготовки в художній гімнастиці та пластики рухів у юних гімнастів. Авторами розроблено та впроваджено в навчально-тренувальний процес власну методику виховання рухово-пластичної виразності, що складалася з наступних компонентів: музично-ритмічної підготовки; оволодіння навичками виразного руху; хореографічної підготовки; вивчення елементів народного і бального танцю.

Мета дослідження - визначити засоби розвитку виразності рухів у складнокоординаційних видах спорту на етапі початкової підготовки та обгрунтувати їх доцільність.

Методи дослідження: теоретичний аналіз науково-методичної літератури та узагальнення практичного досвіду; педагогічні спостереження; бесіди з фахівцями.

Аналіз спеціальної літератури показує, що фахівці виділяють психологічний, мистецтвознавчий і психофізіологічний підходи до розуміння природи виразності рухів. 3 точки зору психології, виразні рухи розглядаються в контексті повсякденного (невербального) спілкування між людьми і розуміються як невід'ємний компонент емоцій людини. Мистецтвознавчий підхід «розглядає» виразність як міру впливу актора на глядача, яскравість втілення змісту сценічного образу. Психофізіологічний підхід дає можливість пояснити виразність рухів ступенем розвитку координації рухів найвищих рівнів, 
Розділ І. Ціннісні орієнтири духовно-інтелектуального виховання, розвиток духовно-інтелектуальних якостей особистості в умовах співпраці й інклюзії

завдяки чому кожна дія людини набуває особливу емоційність і проникливість [2].

У спорті виразність розглядається у контексті експресії рухів уміння поєднувати їх 3 музикою і досягати емоційної дії на глядачів і суддів. Для отримання найвищої оцінки за змагальні виступи спортсмени мають оволодіти вмінням виконувати рухи 3 «підтекстом» (внесення в них смислових відтінків мімікою, жестами) [3].

На нашу думку, вміння передавати рухами протягом змагального виступу певні емоції, пов'язані з музикою, необхідно виховувати починаючи з перших років занять у спортивних секціях. Засоби розвитку виразності рухів юних спортсменів мають підбиратися з урахуванням завдань початкового етапу підготовки у складнокоординаційних видах спорту, зокрема: формування школи рухів, різностороння збалансована загальна і спеціальна фізична підготовка, засвоєння базових навичок на простих хореографічних вправах; розвиток танцювальності, музичності, виразності й творчої активності.

3 огляду на сказане, нами було підібрано наступні групи засобів розвитку рухової виразності у юних спортсменів зі складнокоординаційних видів спорту на початковому етапі підготовки: вправи партерної хореографії сюжетної забарвленості, які мали не тільки вчити дітей володіти різними частинами тіла, а й виконувати ці вправи 3 певними емоціями, наслідуючи поведінку різних живих істот в природі; вправи ритмічної гімнастики, що виховували у дітей здібність гармонійно поєднувати рухи з музикою, засвоюючи елементарні поняття музичної грамоти; танцювальні вправи; вправи ігри (музичні й сюжетно-рольові).

Так, вправи для партерної хореографії мають підбиралися у такий спосіб, щоб поступово вчити юних спортсменів володіти своїм тілом, починаючи від пальців ніг, закінчуючи пальцями рук. Враховуючи, що вправи мають забезпечити не лише фізичну підготовку, а й розвивати виразність рухів, що початковий етап підготовки охоплює дошкільний та молодший шкільний вік, комплексам слід надавати сюжетне забарвлення. Так, перший комплекс «гусінь» включає вправи, що виконуються 3 положення лежачи на спині та на животі з прямими максимально напруженими ногами і руками. Зокрема, до комплексу було включено згинання розгинання пальців ніг, стоп, піднімання прямих ніг і тулуба на $30-45^{\circ}$ по черзі й одночасно, 3 положення лежачи на спині, підні- 
мання таза з опорою на плечі й п'яти, нахили тулуба вперед 3 положення сидячи; упор лежачи на стегнах прогнувшись, вправи в упорі лежачи на передпліччях.

Вправи другого комплексу «лялечка» також починаються 3 положення лежачи на спині, але мають виконуватися в положення або з положення групування. Серед вправ цього комплексу можна виділити наступні: групування 3 положення лежачи на спині в положення сидячи і в положення упор присівши, групування з положення лежачи на боку; перекати в групуванні, як навколо горизонтальної, так і навколо вертикальної осі тіла, а також перекиди вперед і назад з різних вихідних положень, що мали імітувати кокон або «лялечку».

Третій комплекс вправ - «метелик» має виконуватися з положення лежачи на спині, животі й боку та включає високоамплітудні махи вперед, у сторону, назад, ривки прямими ногами в прямі й поперечний шпагати; кола прямими ногами, що нагадують дітям крила метелика.

Вправи наступної групи передбачають використання засобів ритмічної гімнастики і мають виконуватися у положенні стоячи та сидячи й лежачи та включають всі форми рухів головою, руками, ногами й тулубом. Позитивний вплив цих вправ на формування виразності здійснюється їх гармонійним поєднанням 3 музичним супроводом, що підбирається відповідно до віку дітей.

До танцювальних вправ, які ми рекомендуємо використовувати в процесі тренування юних спортсменів для розвитку виразності рухів, відносяться приставні й змінні кроки у різних напрямках, кроки галопу й польки та прості елементи народних танців (копирсалочка, присядка, вірьовочка). Питому вагу у вихованні виразності рухів мають імітаційні танці та сюжетно-образні танці імпровізації, які ми також радимо включати до програми підготовки юних спортсменів, що займаються складнокоординаційними видами спорту. Серед них: хороводи, пов’ язані з природними явищами: «Дощик», «Вітерець», «Хурделиця», «Весна»; хороводи, пов’язані з трудовими діями: «Обжинки», «Рукодільниці», «Рушничок» та імітаційні танці в яких танцюючий наслідує звички звірів або птахів.

До четвертої групи засобів виховання виразності рухів у юних спортсменів ми радимо включати музичні ігри, пов'язані з передачею рухами звучання музики в різному регістрі, ігри на зв'язок рухів з темпом музичних творів та ігри, пов'язані з передачею різних динамічних 
Розділ І. Ціннісні орієнтири духовно-інтелектуального виховання, розвиток духовно-інтелектуальних якостей особистості в умовах співпраці й інклюзії

відтінків музики. А також сюжетно-рольові рухливі ігри, які за своїм змістом потребують перевтілення дітей в живих чи неживих істот.

Отже, у дослідженні підібрано засоби розвитку виразності рухів у юних спортсменів, що займаються складнокоординаційними видами спорту. Доведено, що корисними у вихованні виразного руху можуть бути вправи партерної хореографії сюжетної забарвленості, вправи ритмічної гімнастики, танцювальні вправи та музичні і сюжетно-рольові ігри.

\section{Список використаних джерел:}

1. Горбачева Ж. С. Формирование пластической выразительности в художественной гимнастике : автореф. дис... канд. пед. наук : 13.00.04. СанктПетербург., 2000.

2. Горшкова Е. В. Двигательно-пластическая выразительность и ее развитие в дошкольном детстве. Тезисы V Всероссийского съезда психологов. Санкт-Петербург., 2003.

3. Кабаева А. М. Эстетический компонент соревновательных программ гимнастов. Ученые записки. 2009. № 4(50). С. 54-57.

4. Каравацкая Н. А. Методика формирования навыков двигательной выразительности в художественной гимнастике : автореф. дис. ... канд. пед. наук : 13.00.04. Великие Луки, 2002.

5. Карпенко Л. А., Румба О. Г. Выразительность в гимнастике. Материалы научно-практической конференции, посвященной 100-летию со дня рождения Л. П. Орлова. Санкт-Петербург, 2001. С. 74-77.

6. Кравчук Т., Санжарова Н., Голенкова Ю., Литовко Т. Виховання руховопластичної виразності на етапі спеціалізованої базової підготовки в художній гімнастиці. Педагогіка, психологія та медикобіологічні проблеми фізичного виховання і спорту. 2010. № 12. С. 65-67.

7. Кравчук Т., Санжарова Н., Удовика А. Особливості розвитку пластики юних гімнастів. Теорія та методика фізичного виховання. 2018. № 3(18). C. 148-154. DOI: 10.17309/tmfv.2018.3.05

8. Омельянчик О. О. Стильове забарвлення композиційних послідовностей гімнастичних вправ. Теорія і методика фізичного виховання і спорту. 2001. № 3. C. $19-22$.

9. Тодорова В. Теоретико-методичні основи хореографічної підготовки в техніко-естетичних видах спорту (на матеріалі спортивної аеробіки) : монографія. Львів : ЛДУФК, 2018. 252 с. 